\title{
A Mystery of the Global Surplus and its Ramification
}

Article history

Received: 03 June 2013

Sent for revision: 05 July 2013

Received in revised form: 11 July 2013

Accepted: 13 July 2013

Available online: 15 July 2013

Abstract: This paper deals with phenomenon of the increasingly indicative global imbalances and lagging genesis of balance of payments (BoP) accounting in an attempt to accommodate the ongoing mutation of international trade and finance. Namely, although BoP of the world as a whole should be zero since international trade in goods, services and financial assets ought to be a zero-sum game, our planet apparently runs a non-negligible and rising BoP surplus, projected to reach $1 \%$ of global GDP by 2015 ! To make the puzzle more bizarre, IMF statistics up until 2004 had recorded a persistent BoP deficit for the entire globe, which P. Krugman dubbed "The Mystery of the missing Surplus". Well, surplus is back with the vengeance - while this paper tries to make sense of the phenomenon and pinpoint both its determinants and likely economic consequences. In conclusion, it appears that 1) during international financial crises quality and accuracy of the BoP statistics worsens worldwide, 2) net global imbalances may still be much smaller than we commonly believe, 3) true culprits may not be our usual suspects, 4) gross trade exhibits stark differences once confronted with decomposed valueadded net exports and imports free of double counted processed exports and indirect exporting, 5) also, deliberate misreporting of cross-border investment proceeds as well as MNE's transfer pricing practices may account for a relevant portion of registered global imbalances, and finally, 6) even the latest $6^{\text {th }}$ edition of the IMF's BoP and IIP Manual explicitly tackles but a few of the factors behind the returning surplus mystery.

Keywords: Transfer pricing; Trade; Globalization; Balance of payments imbalances

\footnotetext{
${ }^{1}$ Institute of Economic Sciences , Belgrade, marko.malovic@ien.bg.ac.rs 


\section{Misterija globalnog suficita i njegove posledice}

Apstrakt: $U$ ovom radu bavimo se fenomenom sve indikativnijih globalnih debalansa i kaskajuće geneze računovodstva bilansa plaćanja u pokušaju da obuhvati i dokumentuje aktuelne mutacije u međunarodnoj trgovini i finansijama. Naime, iako bi platnobilansni saldo sveta kao celine trebalo da bude nulti, budući da međunarodna trgovina robom, uslugama i finansijskom aktivom treba da je igra s nultim ishodom, naša planeta ispostavlja se ostvaruje nezanemarljiv i rastući platnobilansni suficit, koji će po projekcijama dostići čak 1\% svetskog BDP do 2015. godine! Da nedoumica bude bizarnija, platnobilansna statistika IMF sve do 2004. detektovala je istrajni platnobilansni deficit svetske privrede, što je $P$. Krugman nazvao "misterijom iščezlog suficita". Međutim, globalni suficit je poput osvetnika ponovo među nama - otud smo ovim člankom pokušali da proniknemo u pomenuti fenomen te identifikujemo kako njegove uzročnike tako i verovatne ekonomske posledice. Zaključci, koji se nameću, mogu se svesti na 6 tačaka: 1) tokom prevashodno međunarodnih finansijskih kriza kvalitet i tačnost platnobilansne statistike pogoršava se u svetskim razmerama, 2) neto globalni debalansi po svoj su prilici ipak mnogo manji nego što se poslovično misli, 3) pravi krivci za debalanse najverovatnije nisu dosad uobičajeno (o)sumnjičeni, 4) međunarodna trgovina u bruto izrazu ispoljava oštra odstupanja u odnosu na standardnu spoljnotrgovinsku statistiku kada se koriguje dekomponovanim neto izvozom baziranim na dodatoj vrednosti i uvozom oslobođenim dvaput zaračunatog procesuiranog i posrednog izvoza, 5) takođe, namerno krivotvorenje prekograničnih prinosa na investicije te manipulacije transfernim cenama od strane MNK skoro sigurno značajno doprinose registrovanim globalnim nesaglasjima, te, konačno 6) čak i najnovije, šesto izdanje priručnika IMF za sastavljanje platnog i obračunskog bilansa eksplicitno tretira jedva par u ovom radu identifikovanih faktora koji su odgovorni za misteriju povratka globalnog suficita.

Ključne reči: transferne cene; međunarodna trgovina; globalizacija; platnobilasna nesaglasja 
"...The world appears to have been running a surplus with itself since 2004." [The

Economist, 2011]

You may want to rephrase this. That is, it sounds suspiciously like the old joke about the two economists stuck on a desert island, who each made $\$ 1$ million by selling the

same shirt to each other.

-Anonymous blogger-

\section{Introduction}

Global imbalances have returned at the forefront of open-economy macro debates in the last couple of years. They have constantly been of interest for maintaining growth-friendly yet ever fragile international economic 'equilibrium' or 'acceptable disequilibrium' in the world economy [Bordo, 2005], but more recently many observers singled them out as unmistakable symptom if not the very root-cause of the global financial crisis and the so-called second great depression [Borio-Disyatat, 2011]. Even before the international financial meltdown, serious concern over arguably unpleasant ramifications of unwinding global imbalances has launched the first blueprints for reform of the post-war international monetary system. Global imbalances themselves are often defined as clearly unsustainable external position of the world's systemically important national economies that reflect distortions or entail risks for the economy of the entire planet. A voluminous and growing literature has been tackling those issues for quite a while now, in parallel with at times rather heated political 'fire exchange', bearing potentially profound consequences for politics, economics or even peace preservation in contemporary international relations.

However, although these issues are very relevant ingredients of the big picture, and will be touched upon in due course, this paper is more directly motivated by another, additional curiosity: namely, it intends to deal with phenomenon of increasingly indicative global imbalance(s) coupled with still lagging genesis of official balance of payments accounting - presumably attempting to accommodate the ongoing mutation of international trade and finance. As a matter of fact, notwithstanding that BoP of the world as a whole should theoretically be zero since international trade in goods, services and financial assets ought to be a zero-sum game, our planet apparently runs a nonnegligible and -in spite of temporary recessional deceleration- rising BoP surplus, still projected to reach $1 \%$ of global GDP by 2015 ! To make the puzzle slightly more bizarre, IMF statistics up until 2004 had recorded a persistent BoP deficit for the entire globe, which P. Krugman dubbed "The Mystery of the missing Surplus" [Krugman-Obstfeld, 2000]. Well, surplus is back with the vengeance - while this paper tries to make sense of the aforementioned phenomenon and pinpoint both its determinants and likely economic consequences. 
In other words, even though more pronounced global imbalances alone (in terms of assets acquired or realised gross trade in goods and non-financial services) among leading economies or regional blocks of the world may well be bad and likely to smell economic and political trouble, ostentatiously growing disequilibrium of the aggregated, world BoP might be yet another alarming symptom sui generis, rather than a mere statistical curiosity! If for no other reason, than because the fairly recent trajectory spanning from clear-cut deficit to non-negligible and most probably yet to be rising surplus of the world's $\mathrm{BoP}$ in just under a decade requires an analytical explanation, thus far not adequately provided by the economic literature nor by the new BoP accounting taxonomy as represented by the sixth and the latest IMF's manual.

The rest of the essay is organised as follows: section 2 offers literature review and some stylized facts on the matter, section 3 deals with the mystery of the global surplus, its causes and possible economic ramifications, while the section 4 goes on to conclude.

\section{Literature Review and Some Stylized Facts on Global Imbalances}

As visible from the Fig. 1, global imbalances reached disturbingly high levels in the mid to late 2000s, unprecedented in the postwar economic era, and have since only temporarily receded due to seriously obstructed international trade and falling manufacturing activity battered against the waves of double dipped recession and protracted financial meltdown that ensued.

The increase in intensity and magnitude of BoP disequilibria of major world players, the wave of often malign innovations sold under the aegis of globalized finance as well as the fact that international forum for global economic governance grew from G-7 to G-20 all in just under a decade, jointly set a specific stage for phenomenon at hand and a relatively rich literature that ensued. Indeed, many reputable authors, featuring but not limited to Bordo (2005), Blanchard (2007), Caballero, Farhi and Gourinchas (2008), Dunaway (2009), Brender and Pisani (2010), Borio and Disyatat (2011), Chinn, Eichengreen and Ito (2011), and not least Gagnon (2011, 2012), investigated the causes and consequences of the recent global imbalances. Classical elasticities framework, utilized for research of global imbalances in earlier literature, models both exports and imports as a function of relative prices and aggregate income in the rest of the world, but since these elasticities tend to be volatile across countries and over time and since trade balance approximated via elasticity approach neglects some potentially important explanatory variables, the authors mentioned above deployed modern panel econometric methodology with more comprehensive fiscal data sets and wider net of variables with statistically relevant explanatory power [Gagnon, 2011]. 
Figure 1 - Evolution of Global Imbalances

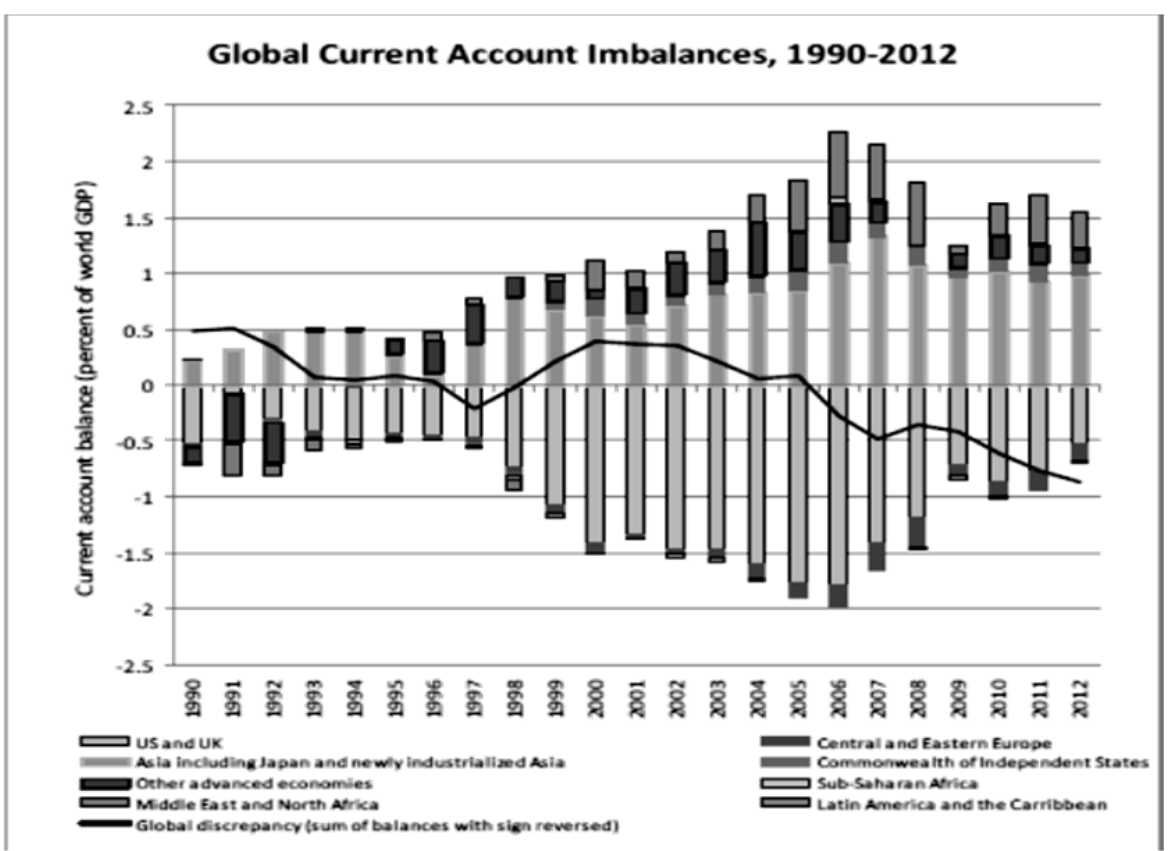

Source: Obstfeld (2012)

Undoubtedly, if we engaged in out of sample forecasts of current account balances for key players in the world economy some 20-25 years ago, our exercise based on methodology sketched earlier would point at 1) high BoP deficits in emerging market countries due to their low(er) wage level, increasing access to technology, high investment, spritely growth and comparatively low propensity to save, whereas 2) rising BoP surpluses in developed economies due to their lower investment, more modest return on investment and higher saving [Blanchard, 2007]. Nevertheless, we have been witnessing exactly the opposite, notwithstanding loads of volatility in data (and sometimes disturbingly unreliable out-of-sample projections by the IMF), it's still evident that many leading OECD members choking in BoP deficits or steeply diminishing surpluses (e.g. USA, Japan), whereas developing countries achieving stunning BoP surpluses (e.g. China, Russia). Consequently, net international capital flows have paradoxically been stemming from the emerging world over to post-industrial developed countries rather than the other way around, which is why growing body of literature has been trying to discern what is going on, will it last, whether global financial crisis has anything to do with it and how/when it may end (see Table 1). 
Malović M.: A Mystery of the Global Surplus and its Ramification

Table 1 - Current Account Balances

(Billions of U.S. Dollars)

\begin{tabular}{|c|c|c|c|c|c|c|c|c|c|c|c|}
\hline & \multirow[b]{2}{*}{2004} & \multirow[b]{2}{*}{2005} & \multirow[b]{2}{*}{2006} & \multirow[b]{2}{*}{2007} & \multirow[b]{2}{*}{2008} & \multirow[b]{2}{*}{2009} & \multirow[b]{2}{*}{2010} & \multicolumn{4}{|c|}{ Projections } \\
\hline & & & & & & & & 2011 & 2012 & 2013 & 2017 \\
\hline Advanced Economies & -2096 & -3838 & -4261 & -3177 & -4821 & -711 & -205 & 933 & -1650 & -1304 & -1851 \\
\hline United States & 285 & -7458 & 8006 & -7103 & 677.1 & -381.9 & -420 & 4659 & 4865 & 4992 & 679 \\
\hline Euro Area ${ }^{12}$ & 121.7 & 514 & 53.7 & 456 & .998 & 182 & 488 & 566 & 1360 & 151.7 & 2374 \\
\hline Japan & 1721 & 1661 & 1709 & 2121 & 1599 & 1466 & 2040 & 1193 & 954 & 1378 & 1276 \\
\hline Other Advanced Economies ${ }^{3}$ & 1251 & 1445 & 1499 & 1349 & 1350 & 146.1 & 1686 & 1968 & 90.1 & 793 & 137.7 \\
\hline $\begin{array}{l}\text { Memorandum } \\
\text { Newly Industrialized Asian } \\
\text { Economies } \\
\text { Emerging Market and } \\
\text { Developing Economies }\end{array}$ & 2064 & 4169 & ஐ95 & 626 & $\mathbf{6 3 7}$ & 1238 & 3362 & 4812 & $\begin{array}{r}121.0 \\
3618\end{array}$ & 3101 & 2583 \\
\hline Regional Groups & & & & & & & & & & & \\
\hline $\begin{array}{l}\text { Central and Eastem Europe } \\
\text { Commonwealth of Independ- } \\
\text { entStates }{ }^{4}\end{array}$ & -561 & 613 & -89.0 & -1363 & -1599 & 495 & 814 & -1166 & -906 & 946 & -1459 \\
\hline $\begin{array}{l}\text { Developing Asia } \\
\text { Latin America and the }\end{array}$ & 924 & 1412 & 2683 & 3999 & 4058 & 2969 & 2336 & 1882 & 1186 & 1496 & 4669 \\
\hline Caribbean & 221 & 359 & 487 & 132 & 322 & -21.9 & -574 & -737 & -97.1 & -1112 & -180.7 \\
\hline Middle East and North Africa & 91.7 & 2149 & 2867 & 204 & 3548 & 529 & 1825 & 3921 & 3614 & 329.5 & 2196 \\
\hline Sub-Saharan Africa & -82 & -14 & 285 & 108 & -25 & -283 & -131 & -206 & 41.0 & 457 & -704 \\
\hline $\begin{array}{l}\text { Memorandum } \\
\text { European Union }\end{array}$ & 668 & 79 & -275 & 61.7 & -171.6 & -02 & 5.7 & 345 & 824 & 111.0 & 2325 \\
\hline $\begin{array}{l}\text { Analytical Groups } \\
\text { By Source of Export } \\
\text { Eamings }\end{array}$ & & & & & & & & & & & \\
\hline Fuel & 1755 & 3547 & 4821 & 4358 & 5964 & 1483 & 3314 & 6124 & 5776 & 5151 & 2503 \\
\hline $\begin{array}{l}\text { Nonfuel } \\
\text { OfWhich, } \\
\text { Primary }\end{array}$ & 309 & 623 & 1574 & 1938 & 773 & 1434 & 48 & -131.1 & -2158 & -2051 & 80 \\
\hline $\begin{array}{l}\text { Produds } \\
\text { By Extemal Finanaing } \\
\text { Source }\end{array}$ & -12 & -32 & 65 & 52 & -17.0 & -87 & 87 & -226 & 355 & 335 & -259 \\
\hline $\begin{array}{l}\text { Net Debtor Economies } \\
\text { OfWhich, Official }\end{array}$ & 612 & -896 & -1192 & -2292 & $-3 / 58$ & -190.7 & -2822 & 3648 & 4993 & 4178 & 4397 \\
\hline $\begin{array}{l}\text { Finanding } \\
\text { Net Debtor Economies by } \\
\text { Debt-Servicing }\end{array}$ & -52 & -60 & 35 & -51 & -123 & -9.0 & -11.0 & -130 & -181 & -148 & -192 \\
\hline Experience & & & & & & & & & & & \\
\hline $\begin{array}{l}\text { Economies with Arrears } \\
\text { and/or Resdheduling } \\
\text { during 2006-10 }\end{array}$ & 37 & -54 & 4.1 & -14.1 & -274 & -235 & 335 & 428 & -505 & 482 & -60.5 \\
\hline World $^{1}$ & -32 & 332 & 2134 & 3119 & 1916 & 2207 & 3157 & 3879 & 1968 & 1796 & $\mathbf{7 3 1}$ \\
\hline
\end{tabular}

Source: IMF (2012) 
Synthesizing the more recent work enlisted above, one can identify some six main schools of thought (not necessarily mutually exclusive) in respect to determinants of the global imbalances:

- Fiscal stance and a twin deficits paradigm

- Global savings glut

- Intertemporal approach

- Mercantilist view

- Hoarding official net foreign assets

- Oil shocks.

Fiscal stance view in its unsophisticated version assumes that macroeconomic shocks hit exclusively or at least predominantly government sector, which renders budget deficit quasi-exogenous and via twin deficit identity plagues the current account [Chinn-Eichengreen-Ito, 2011]:

$$
B=X-M<=T-G+S^{P}-I
$$

However, the well-known identity shown in (1) simply says that sum of accumulation (both private and public savings) and BoP balance must be post festum equal to the sum of fiscal balance and private investment undertaken, without any stricto sensu and generally established causation. Be that as it may, the inspiration for this perspective, namely Regan 1980s period of tax cuts and simultaneous budget and BoP deficits, amount to just one eventuality of foreign savings alimenting for the entire budget deficit. If the country's own residents end up financing the fiscal deficit, as easily shown in the Mundell-Fleming framework, the only immediate consequence would be the socalled crowding out effect and the rise of interest rate. By and large, even though both of the twin deficits may well be codetermined, higher fiscal deficits through financial market channel do shoot up reference rates, thereby putting downward pressures to exchange rates and to respective current accounts. Hence, budget deficits (at least in the aftermath of bold fiscal expansion in some leading economies) are now believed to be more important determinant of global imbalances than previously thought - BoP balance tends to pick up $20-30 \%$ of any increase in the fiscal balance, as contrasted with 10 $20 \%$ found in previous generation research [Gagnon, 2012].

Global savings glut, in addition, owes its name to FED Chairman Bernanke's observation that, following bitter experiences of Southeast Asian and alike crises and throughout the beginning of millennium, there's been too many savings accumulated around the world in comparison with readily available investment opportunities, which led global savings (and savers) to finance other nations' current account deficits instead of their own business undertakings. Apart from the strong desire by many developing economies to insure themselves against future speculative currency attacks global savings glut 
has been delivered by convergence of factors: Middle Eastern oil exporters had sought ways to deploy their oil earnings in a safe and dynamic markets

\section{Figure 2 - Evidence of Global Savings Glut}

Global savings rate, GDP growth and interest rates

In per cent

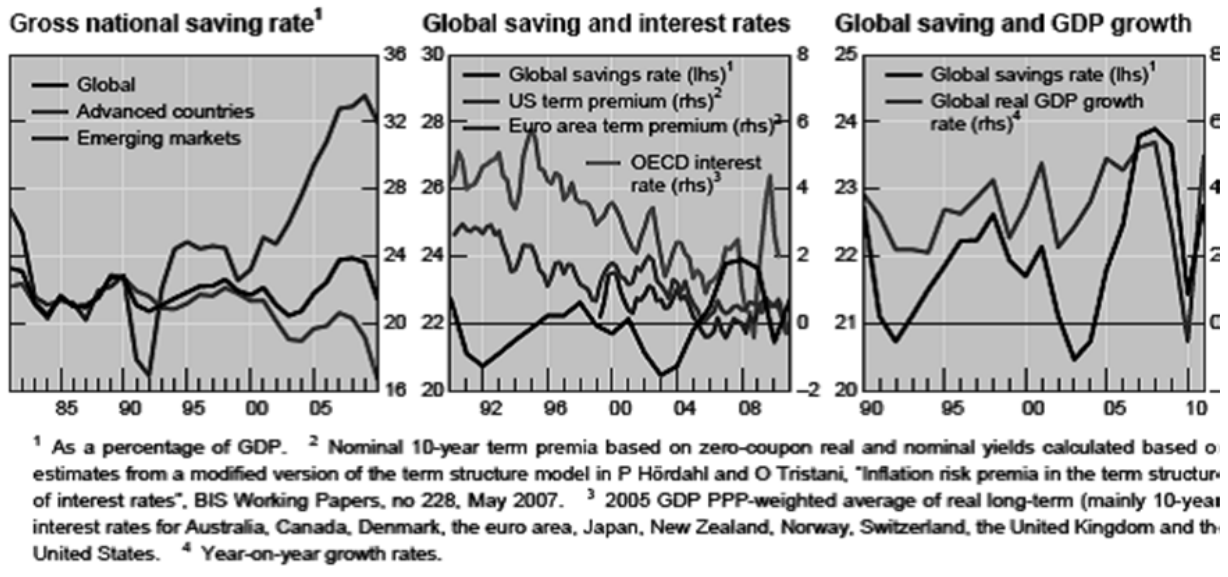

Source: Borio and Disyatat (2011)

and denominations, Japan and Germany expectedly lifted their savings rates in face of their swiftly aging populations, while countries with underdeveloped and still highly administered financial systems, like China for instance, had wanted to diversify into safer assets [Blanchard, 2007], [Reinhart-Rogoff, 2009], [Dunaway, 2009], [Song-Storesletten-Zilibotti, 2011]. Moreover, another way of expressing global savings glut argument is the so-called CaballeroFarhi-Gourinchas hypothesis, according to which countries with deeper and wider financial markets are expected to have weaker current accounts, since they acquired relative advantage in producing safe and sound (internationally sought) financial assets [Caballero-Farhi-Gourinchas, 2008]. Either way, as evident from Fig. 2, this excess savings flowed upstream in (international) financial centres of advanced economies (particularly the US), dangerously relaxing borrowing conditions over there and worldwide in the process [Borio and Disyatat, 2011].

Intertemporal approach nurtures mathematically rigorous analysis of global imbalances, according to which consumption today equals a share of net present (discounted) vale of future expected output, or wealth in net terms. Consequently, current account dynamics in intertemporal framework is modeled as a function of interest rate and the interplay between the expected future 
output (tantalizingly hard for reliable quantification) and the current national output [Chinn-Eichengreen-Ito, 2011].

Mercantilist view sees global imbalances as a ramification of export led growth strategies of (mostly Asian) developing countries, with many government interventions overtly or covertly supporting export-oriented industries. Balassa-Samuelson effect and occasional inward FDI booms aside, mercantilist view underlines that if real exchange rates in those countries are artificially held constant over longer periods of time, global imbalances would inevitably widen [Chinn-Eichengreen-Ito, 2011], [Gagnon, 2012].

Hoarding of official net foreign assets is often being similarly portrayed as the defensive flip-side of insufficient (real) exchange rate flexibility [Gagnon, 2011]. After all it is well known that when balance of payments of a given country exhibits huge disequilibrium (anything of 5\% of GDP and greater magnitude), there must be something wrong with the currently prevailing value of respective domestic currency's parity. Put differently, the currency manipulation thesis rests on the simple postulate that the external imbalance itself is evidence of a misalignment of the exchange rate. Letting market forces determine the exchange rate would restore trade balance [SongStoresletten-Zilibotti, 2011]. This argument has insufficiently persuasive theoretical as well as empirical foundations. First of all, the argument merits sound theoretical underpinning if and only if country's net foreign assets aren't mismeasured, otherwise larger than official estimates of a "dark matter" throw different light on key players' ability to finance their BoP deficits, most of all the US [Reinhart-Rogoff, 2009]. Mutatis mutandis, currency manipulation thesis is still more typically objected to China as a large BoP surplus economy. Mismeasurement in either current or financial part of the BoP put aside, what matters in this business is the real exchange rate, not the nominal one. While the Chinese surplus has persisted for almost twenty years, the renminbi real exchange rate has remained as flat as a crape [McKinnon, 2006]. A misaligned real exchange rate would surely feed domestic inflation by stimulating the demand for non-tradables and by strengthening domestic wage pressure. However, Song, Storesletten and Zilibotti (2011) observed that until very recently China hadn't experienced any significant inflationary pressure - in fact, between 1997 and 2007 the inflation rate had been on average about the same as in the US. Furthermore, wages had risen slower than output per worker [lbidem]. After all, with exactly the same exchange rate, China runs BoP deficits with Japan, Taiwan and South Korea.

Nonetheless, hoarding of official reserves may happen not only in the form of FX purchase in order to ward off unappealing currency appreciation, but for additional two reasons as well: as amassing conventional external (sovereign) debt incurred to fund a longer-term development project, or as obtaining safe foreign assets for precautionary or saving purposes [Blanchard, 2007], [Gag- 
non, 2011]. These last two might represent empirically valid, unbiased factors of BoP dynamics in some instances.

Finally, unprecedented oil price hikes we've been witnessing for the last 6-7 years undoubtedly contributed considerably to antagonizing global imbalances between oil exporters and the rest of the world, in absence of revolutionary new technologies or larger scale expansion of defense industries that advanced members of OECD resorted to during the previous two global oil crises (1973-74 and 1979-80). By setting up investment funds to safeguard most of the oil proceeds, petrol exporters initially flooded the US and EMU financial markets with global liquidity yet again, thereby increasing both claims to those foreign assets and global financial leverage, leverage which extended imbalances into cascades of the international financial crisis. Ramification of their subsequent jump into investment conservatism is to be discussed later.

Overall, it is evident that more work is needed in the topic of global imbalances and their origins based on both sharper theoretical rigor and less ambiguous empirical specifications. Most of the theories reviewed rely on little else than econometric tautologies (regressing variables on more or less their mathematical identities with ad hoc implied causality or specific structure), running risks of simultaneity bias, multicolinearity, reverse causality, failing to differentiate between savings and financing, or domestic saver-drought vs. foreign investment boom and alike. Several theories represent but a mirrorimage of another already circulating theory rather than profoundly new evidence on either determinants or ramifications of the global imbalances. None of the theories explains why global imbalances grew bigger than ever before, let alone how come that global current account surplus recently overthrew aggregate BoP deficit. These issues are to be dealt with in the next, central section of the paper.

\section{Global BoP Surplus - a raging beacon or a statistical curiosity?}

As explained earlier, in principle, combined (inter)national BoP surpluses and deficits of countries, territories and organisations ought to add up to zero, in practice, however, due to measurement mismatches and international politicoeconomic constellation of the day, data do not offset each other, causing not only continuous global BoP imbalances, but also occasional changes in the sign of the global current account disequilibrium. 
Malović: A Mystery of the Global Surplus and its Ramification

Table 2. World's (Aggregated) BoP Statistics

(In billions of U.S. dollars)

\begin{tabular}{|c|c|c|c|c|c|c|c|c|}
\hline & 2004 & 2005 & 2006 & 2007 & 2008 & 2009 & 2010 & $\begin{array}{c}\text { Average } \\
\text { AbsoluteValue } \\
\text { 20042010 } \\
\end{array}$ \\
\hline Cumentaccountbalance $^{*}$ & 529 & 50.4 & 213.7 & 355.1 & 257.5 & 266.0 & 399.8 & 227.9 \\
\hline Balanœongoods & 39.9 & 50.3 & 123.9 & 190.6 & 144.7 & 182.0 & 2842 & 145.1 \\
\hline $\begin{array}{l}\text { Credit } \\
\text { Debit }\end{array}$ & $\begin{array}{l}9.064 .9 \\
9,025.0\end{array}$ & $\begin{array}{l}10.373 .9 \\
10,323.5\end{array}$ & $\begin{array}{l}12005.6 \\
11,831.7\end{array}$ & $\begin{array}{l}13.905 .7 \\
13,715.1\end{array}$ & $\begin{array}{l}16,019.7 \\
15,875.0\end{array}$ & $\begin{array}{l}12,4122 \\
12230.1\end{array}$ & $\begin{array}{l}151353 \\
148511\end{array}$ & \\
\hline $\begin{array}{l}\text { Balanceonservices } \\
\text { Credit } \\
\text { Debit } \\
\text { of which: }\end{array}$ & $\begin{array}{r}54.8 \\
2277.4 \\
22226\end{array}$ & $\begin{array}{r}76.6 \\
2,537.9 \\
2,461.3\end{array}$ & $\begin{array}{r}1272 \\
2,878.6 \\
2751.4\end{array}$ & $\begin{array}{r}206.5 \\
3,457.3 \\
3250.8\end{array}$ & $\begin{array}{r}1726 \\
3,884.3 \\
3.711 .7\end{array}$ & $\begin{array}{r}1362 \\
3,450.0 \\
3.313 .9\end{array}$ & $\begin{array}{r}140.8 \\
3,765.7 \\
3,624.8\end{array}$ & 130.7 \\
\hline Transportation & -104.5 & -116.6 & -1312 & -137.1 & -166.1 & -134.6 & -180.7 & 138.7 \\
\hline $\begin{array}{l}\text { Travel } \\
\text { Govermmentsenvices }\end{array}$ & $\begin{array}{l}49.1 \\
-40.1\end{array}$ & $\begin{array}{r}47.3 \\
-40.9\end{array}$ & $\begin{array}{r}65.5 \\
-50.9\end{array}$ & $\begin{array}{r}75 \\
-527\end{array}$ & $\begin{array}{r}89.7 \\
-79.5\end{array}$ & $\begin{array}{r}74.1 \\
-81.7\end{array}$ & $\begin{array}{r}862 \\
-82.3\end{array}$ & $\begin{array}{l}69.6 \\
612\end{array}$ \\
\hline Otherservices & 150.4 & 186.8 & 243.8 & 321.3 & 328.6 & 178.3 & 317.8 & 261.0 \\
\hline Balanœonincome & -21.5 & -51.3 & -49.9 & -45.4 & -73.7 & -44.3 & -8.6 & 421 \\
\hline $\begin{array}{l}\text { Credit } \\
\text { Debit } \\
\text { ofwhich: }\end{array}$ & $\begin{array}{l}1,893.7 \\
1,9152\end{array}$ & $\begin{array}{l}2,433.3 \\
2,484.6\end{array}$ & $\begin{array}{l}3,140.9 \\
3,190.9\end{array}$ & $\begin{array}{l}4,052.6 \\
4,098.0\end{array}$ & $\begin{array}{l}4,001.8 \\
4,075.5\end{array}$ & $\begin{array}{l}2,948.3 \\
2,9926\end{array}$ & $\begin{array}{l}3,079.3 \\
3,087.9\end{array}$ & \\
\hline $\begin{array}{l}\text { Compensation of emplyyees } \\
\text { Reinvestedeamings } \\
\text { Otherdiredinvestmentin- }\end{array}$ & $\begin{array}{r}-7.6 \\
136.4\end{array}$ & $\begin{array}{r}-11.5 \\
72\end{array}$ & $\begin{array}{r}-13.5 \\
1602\end{array}$ & $\begin{array}{l}-17.1 \\
193.3\end{array}$ & $\begin{array}{r}-24.7 \\
163.8\end{array}$ & $\begin{array}{r}-20.8 \\
176.9\end{array}$ & $\begin{array}{r}-10.6 \\
198.6\end{array}$ & $\begin{array}{r}15.1 \\
148.0\end{array}$ \\
\hline $\begin{array}{l}\text { come } \\
\text { Portfolioand dotherinvestment }\end{array}$ & -262 & 824 & -86.9 & -135.7 & -992 & -124.8 & -127.6 & 97.5 \\
\hline $\begin{array}{l}\text { income } \\
\text { Balanceon aurenttransfers }\end{array}$ & $\begin{array}{r}-124.1 \\
-20.4\end{array}$ & $\begin{array}{r}-129.4 \\
-25.3\end{array}$ & $\begin{array}{r}-109.8 \\
126\end{array}$ & $\begin{array}{r}-85.9 \\
3.4\end{array}$ & $\begin{array}{r}-113.6 \\
13.9\end{array}$ & $\begin{array}{r}-75.7 \\
-7.9\end{array}$ & $\begin{array}{r}-69 \\
-16.6\end{array}$ & $\begin{array}{r}101.0 \\
14.3\end{array}$ \\
\hline $\begin{array}{l}\text { Credit } \\
\text { Debit }\end{array}$ & $\begin{array}{l}6042 \\
624.5\end{array}$ & $\begin{array}{l}690.6 \\
715.9\end{array}$ & $\begin{array}{l}764.4 \\
751.8\end{array}$ & $\begin{array}{l}873.9 \\
870.5\end{array}$ & $\begin{array}{l}981.3 \\
967.4\end{array}$ & $\begin{array}{l}923.1 \\
931.0\end{array}$ & $\begin{array}{l}9232 \\
939.8\end{array}$ & \\
\hline $\begin{array}{l}\text { Memorandumitems } \\
\text { Currentacoountbalanœeasper- } \\
\text { centofgross a urentacoount }\end{array}$ & & & & & & & & \\
\hline $\begin{array}{l}\text { transadions } \\
\text { Goods balanceas percentof } \\
\text { gross goodstransadions } \\
\text { Services balanceis percent of }\end{array}$ & 02 & 02 & 0.5 & 0.8 & 0.5 & 0.7 & 0.9 & \\
\hline $\begin{array}{l}\text { grossservicestransadions } \\
\text { Incomebalanceaspercent of }\end{array}$ & 12 & 1.5 & 23 & 3.1 & 23 & 20 & 1.9 & \\
\hline $\begin{array}{l}\text { grossincometransadions } \\
\text { Cumenttransfers balanœeasper- } \\
\text { centofgrossamenttransfer } \\
\text { transadions }\end{array}$ & 0.6 & 1.8 & 0.8 & 0.6 & 0.9 & 0.7 & 0.1 & \\
\hline
\end{tabular}

Source: IMF (2011)

According to IMF (2011), as summed up in Table 2, the global current account balance was consistently positive in 2004-2010 period and likely to remain 
such beyond, after a long period of aggregated deficits. ${ }^{2}$ Thus, global BoP discrepancies reflect incomplete coverage of international transactions, inaccurate or inconsistent recording by compiling countries (and/or reporters), differing classifications or unsynchronised accounting in tackled national BoPs [IMF, 2004, 2010], but also the consequences of ruling economic ideologies of the time, like Lawson's doctrine, mercantilist zeals and alike [Obstfeld, 2012.

Be that as it may, it is evident from Table 2 that global BoP surplus increased in 2010 for astonishing 134 billion US\$ from its 2009 level. As well as the more recent and likely-to-be-temporary decrease in the dynamics of global surplus growth in 2011 and 2012 [see IMF, 2012], previously mentioned increase (after another sharp contraction caused by the global financial crisis back in 2009) is arguably also to be attributed mainly to the growing imbalance in international trade (in goods and perhaps some embedded services ${ }^{3}$ ), rather than international financial flows or investment income majority of researchers have been focusing at.

In either case, what is going on as prerequisite for the mystery of the global surplus on such a scale (global BoP surplus recently exceeded China's current account surplus) must be systemic and asymmetric misreporting, so that BoP deficits of countries like the US have had to be ever more overstated and/or BoP surpluses of emerging market economies like China have had to be increasingly exaggerated [The Economist, 2011*]. Let us briefly examine the likely grass-roots (both pure and monetary) as well as ramifications of the phenomenon at hand.

Previous research typically earmarked externally earned but underreported or unreported investment income (interest, dividends, rents and so on) as principal culprit of once large global BoP deficit in the late 1980s and 1990s [Motala, 1997]. Most of that still largely missing net factor payments income has simply melted in both absolute and relative terms following the free fall of the world interest rates, thus pushing the global balance towards the surplus zone, but partly also because after the initial wave of the global financial crisis, EU and US governments have cracked down on off-shore financial centres and tax evasion to that end.

\footnotetext{
2 Sometimes statistical and methodological revisions, reflecting previously incomplete or unavailable data and recalculation of external positions following newly introduced manuals for BoP book-keeping, significantly alter earlier findings [IMF, 2009]. Examples could be the outlier represented by an unusual global net receipt in 1997 [IMF, 2004], or indeed even slightly increased global BoP deficit in 2004 vis-à-vis 2003 as recorded by the IMF (2005) which had subsequently been revised to a surplus as evident in the $\operatorname{IMF}(2010,2011)$ publications.

${ }^{3}$ Gross trade figures had suggested that services account for only 20 percent of global trade. Nevertheless, value-added breakdown revealed that the average for OECD countries is around 50 percent, with multiple services such as software and design increasingly embedded in tradable goods [Wheatley, 2013].
} 
Therefore, principal causes of the global surplus mystery must lay elsewhere. Part of the explanation lurks in never heftier freight receipts which -due to skyrocketing oil price and the time lag between recording it in BoPs of importer and service provider- demonstrate an obvious export-bias. Moreover, unlike the first and second oil shock back in the 1970s, this time around Middle East and the rest of oil exporters have been pretty much sitting on their petrodollar wealth (once they understood the asset bubble risks of cheap money), instead of investing it more boldly back into financial system of advanced oil importers [The Economist, 2012]. Hence, not only individual external imbalances got larger but also contemporary terms of trade changed dramatically in comparison to the late 1990s, with greatest trade deficits and surpluses coinciding with the crude oil price hikes in 2007 and 2011. In other words, during overwhelmingly international financial crises and oil shocks, structural breaks occur, policies are inclined to exhibit backward looking design, while quality and accuracy of the BoP statistics typically worsens worldwide, especially so in less developed countries. Further still, some other service-exports (e.g. tax\&legal, consulting and certain types of insurance) tend to go unnoticed from the importer's authorities' perspective even at reasonably tranquil times [The Economist, 2011*]. ${ }^{4}$ Finally, at least two distinct international business practices with expanding spillover effects deserve separate analytical attention in respect to their ability to shed some additional light on the global surplus mystery.

One is the emergence of global supply chains with multistage, sliced up production scattered across different territorial entities, which render traditional trade data increasingly unreliable guideline to policymaking. Worse still, surprisingly little is known - quantitatively speaking - about how the rise of global supply chains has changed the mechanics and the very meaning of trade balance adjustments, the various costs and benefits of protectionism or more broadly of trade agreements, and not least the propagation of proximityadjusted trade shocks through highly entangled national economies [Koopman-Wang-Wei, 2012], [Johnson-Noguera, 2011]. More precisely, I implicate quite recently raised awareness, in regard to stark discrepancies between 'value-added exports' - defined as the amount of value added from one country yet consumed in another - and changes in gross exports traditionally recorded by customs authorities and official trade statistics, into the controversy of global surplus. As a matter of fact, conceptual shortcoming of formally recorded trade flows becomes apparent once one comprehends they are measured as well as published in gross terms, inclusive of intermediate inputs, raw materials and final products, thereby double counting the value of all intermediate goods which cross customs territories more than once

\footnotetext{
${ }^{4}$ For the sake of the argument, law firms involved in cross-border deals are usually quite big, whereas most clients' spending on legal services is relatively minute, keeping it either entirely invisible or under the threshold of surveys utilised in tracking the trade in services [lbidem].
} 
[Koopman-Wang-Wei, 2012]. For example, the factory-gate price of the Apple's iPhone -- \$187.51 in 2010 -- had shown up in full in China's gross export figures, even though according to estimates provided by consulting firms iSuppli and Chipworks, Taiwan was the origin of $\$ 20.75$ of the value, Germany of $\$ 16.08$, S. Korea of $\$ 80.05$, the United States of $\$ 22.88$ and others, including Japan, the origin of $\$ 47.75$ [Wheatley, 2013]. Moreover, Johnson and Noguera (2011) and Wheatley (2013) document that proper exclusion of double counting in vertically specialised production and trade flows reduce actual BoP surpluses of most prominent outliers by $1 / 4$ in the case of China up to no less than by $2 / 3^{\text {rds }}$ in the case of smaller (re-)export processing champions in world trade. The actual tracking of value-added in global supply chains consists of several algebraic steps adapted from pioneering work by Johnson and Noguera (2012) and Koopman, Wang and Wei (2012). In a world populated by $\boldsymbol{N}$ countries and $\boldsymbol{H}$ industries in each given year $\boldsymbol{t}$, gross value of $\boldsymbol{i}$-th exporter's output in the source industry $\boldsymbol{\sigma}$ can be written as:

$\boldsymbol{y}_{i t}(\boldsymbol{\sigma})=\sum_{j=1}^{N} f_{i j t}(\sigma)+\sum_{j=1}^{N} \sum_{\delta=1}^{H} \mu_{i j t}(\sigma, \delta)+\boldsymbol{d}_{\text {fit }}+\boldsymbol{d}_{\text {ait }}, \forall \boldsymbol{i} \neq \boldsymbol{j}$

First term on the right hand side represents the value of final goods shipped from source industry $\boldsymbol{\sigma}$ in country of origin $\boldsymbol{i}$ to destination country $\boldsymbol{j}$, second amounts to value of intermediates from industry $\sigma$ in source country $i$ exported to destination industry $\boldsymbol{\delta}$, whereas $\boldsymbol{d}_{\text {fit }}$ and $\boldsymbol{d}_{\text {ait }}$ denote domestic industry goods for national final consumption and domestic industry goods for intermediate input use. Therefore, officially recorded gross exports -from origin $\boldsymbol{i}$ to destination country $\boldsymbol{j}$ - collapse to the first two terms of equation (1), and could be formalized as $\boldsymbol{H x} \mathbf{1}$ vector:

$x_{i j t}=f_{i j t}+A_{i j t} y_{j t}, \forall i \neq j$

First right hand side term in (3) is vector of exports for final consumption elsewhere, while the new variable in second term represents familiar $\boldsymbol{H} \boldsymbol{x H}$ input-output matrix of technical coefficients compulsory for unit production of foreign (final or intermediate) good in destination country $\boldsymbol{j}$, so that $\boldsymbol{A}_{i j t}=\boldsymbol{\mu}_{i j t}(\sigma, \delta) / \boldsymbol{y}_{j t}(\delta)$. Similarly, global gross output could be depicted via input output matrix so that:

$y_{t}=A_{t} y_{t}+f_{t}=\left(I-A_{t}\right)^{-1} f_{t}=\Lambda_{t} f_{t}$

where $\Lambda_{t}$ denotes well-known Leontieff inverse block matrix, also referred to as the total requirement coefficients. Leontieff inverse matrix answers how much global output (from any country and each industry) is compulsory to create a given vector of final goods tantamount to total world's final consumption. Now, by definition of technical coefficients $a_{i j}$ which populate the input- 
output matrix, matrix of domestic value-added in each country's gross output should consist of residual $v_{i}$ elements defined as:

$v_{i}=1-a_{i 1}-a_{i 2}-\ldots-a_{i N}$

So produced matrix $\boldsymbol{V}$ (whose main diagonal elements only contain non-zero increments) ought to be multiplied by Leontieff block matrix to yield valueadded share matrix $\mathbf{V} \boldsymbol{\Lambda}$, which is likewise $\boldsymbol{V}$ itself also a $\mathbf{N x} \mathbf{N H}$ size matrix.

At last, value-added net export can be obtained after multiplying the matrix containing only the main diagonal elements of $\boldsymbol{V} \boldsymbol{\Lambda}$ (the rest of them being zero) with extracted gross output matrix:

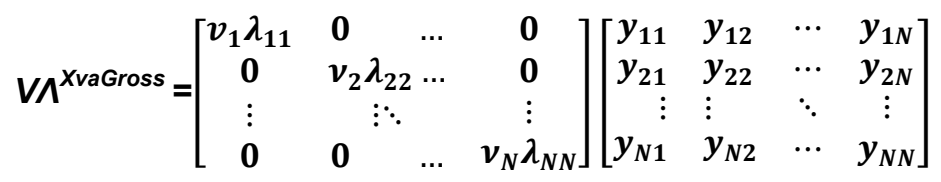

Therefore, scalar equivalent of gross value-added exports (distinct and obviously smaller than gross exports traditionally recorded by official trade stats) is computed by summing up all the elements of the matrix yielded as the product of the above multiplication written in equation (6):

$X^{\mathrm{VA} \text { Gross }}=V_{i} \sum_{i \neq j}^{N} \sum_{g=1}^{N} \lambda_{\iota g} f_{g j}$

However, if one desires to exclude value-added produced by the source country that gets repatriated after being processed overseas, as we indeed rightfully should, Koopman, Wang and Wei (2012, p.31) intelligently conclude that the holy grail of net value-added exports (that official statistics would ideally want to capture) amounts to summation of elements in the off-diagonal space of the $V \Lambda^{X v a G r o s s}$ matrix only! Put differently, net value-added exports must exclude from gross exports all doubly counted items - namely not only foreign value added but also the portion of exported domestic value added which was imported back into the country at some later stage:

$X^{\mathrm{VA}: N e t}=V_{i} \sum_{g}^{N} \lambda_{\iota g} f_{g j}$

Although exact data are still being gathered, it's safe to say that double counting is to be blamed for handsome part of the global imbalances currently in motion. Once again, oil shocks have undoubtedly slashed the amount and frequency of long-distance trade patterns, while in their cross-section data, Johnson and Noguera (2011) found that the ratio of value-added to gross exports tends to be higher for trade partners separated by long distances, implying that gross trade ended up being increasingly localised relative to 
value-added trade. What about global BoP surplus itself? According to Johnson and Noguera (2012), the largest declines of value-added as opposed to gross exports tend to be concentrated in emerging markets with fast growing manufacturing. Now, those countries have had not only traditionally less reliable trade statistics and more shuttle trade cum outright smuggling over their often somewhat fragile borders, but also since the onset of global financial crisis and return of depression economics authorities in majority of them offered non-negligible if sometimes stealthy export stimulations on roll-over basis to their firms both state-owned and private, which creates additional incentive for exporters to artificially inflate their export achievements as well as to depress their true import quantities.

Moreover, reevaluating trade flows, entire current account and international financial flows in the global BoP by means of value-added real effective exchange rate methodology newly developed by Bems and Johnson (2012) on the backbone of identical arguments laid out in the passages above, are likely to give us additionally corrected and analytically improved view of the global surplus, thus far still distorted by mainstream trade statistics- and exchange rate determination methodologies. In particular, by allowing vertical specialisation in trade, Bems and Johnson (2012) derive a value-added real effective exchange rate which essentially describes how demand for the national value added varies according to changes in the price of its added value relative to competitors'. Staggering gaps between conventional real effective exchange rates and their value-added counterparts prove to be robust evidence of somewhat exaggerated global imbalances: for instance, China's value-added real effective parity appreciated 20 percentage points more than conventional real effective exchange rate in 2000-2009 period [Ibidem].

The second international business practice worth dwelling on in regard to global surplus mystery is exploding transfer pricing manipulation carried out predominantly (yet not exclusively) by transnational and multinational corporations. Coupled with asymmetric quality of accounting and audit of international transactions across countries, transfer pricing at first used to be focused at dwindling the value of imported technology, blueprints, machinery or intermediates into the host country's affiliates, due to ad valorem nature of duties levied. However, since (at least for WTO members) effective rate of customs protection fell to comparatively low levels, multinationals are nowadays primarily concerned with tax evasion. Therefore, royalties charged for technology transfers and know-how became astronomical in order to mask the true volume of profit made overseas, while those very same imports of technology, blueprints, machinery or intermediates into the host country's affiliates were deliberately overestimated so as to artificially minimize the taxable base for VAT charges. Such elaborate scams have twofold ramification in respect to global surplus mystery. First of all, it raw-deals, shuffles and reshuffles manufacturing activity, profits and trade flows until much larger pecuniary weight is 
attained within more porous borders and lower tax-jurisdictions of countries with traditionally weaker capacities for accurate and timely BoP accounting. And secondly, uncollected corporate tax and VAT levies in turn crack-open potentially dangerous holes in national public budgets which tend to further complicate BoP disequilibria and global imbalances, even in OECD countries with typically stronger economies and more reliable trade statistics.

Furthermore, in (eminently emerging) economies with heavy administrative walls and red tape in cross-border capital and financial transactions, it has become anything but seldom to encounter capital-controls-circumventing over- or underinvoicing, this time as a round-tripping strategy without particular tax-evading motives whatsoever. Similarly, in deeply unsettling parts of the world, phenomena like political risk, armed conflict or organised crime have provoked steady capital flight with asymmetric BoP ramification, to this day obviously not equilibrated on the globally aggregated level. Finally, some probably underrecorded capital flight over the course of the global financial meltdown took place for mere flight to quality reasons.

Some of these developments could be suspected from capital and financial account data in the overall BoP (rising international indebtedness, FDI and portfolio investment reversals), some from technological BoPs which are constructed separately, yet majority of them is likely to be obscured by the generic position of net errors and omissions (see Table 3). Although, as far as numbers can hint us, financial and capital transactions as of late seem to be largely compensatory in nature, cyclical and quantitatively rather volatile behaviour of global net errors and omissions account signalises non-negligible incidence of misreporting. Moreover, many errors and omissions may cancel each other out, so that data in Table 3 may not even capture the full extent of discrepancies. In addition, in spite of the fact that the latest IMF's manual for BoP statistics provides certain alterations to improve on the historical practice ${ }^{5}$, some transactions in the financial account are still being recorded on a 'net: gross' basis ${ }^{6}$, leaving the ambiguity that actual volume of cross-border traffic in portfolio investment and alike remains much larger than officially recorded.

\footnotetext{
5 Imperative of f.o.b. accounting and maximal differentiation between goods and therein embedded services, increased sensitivity and robustness in accounting for the activities of multinationals, more rigorous screening of international remittances, imputed transactions and capital transactions due to change of residence, explicit recognition of satellite accounts, all capital account and FDI transactions to be recorded on a gross basis etc. [IMF, 2009].

${ }^{6}$ Accounting for capital transactions in 'net:gross' fashion means that sales and purchases of international financial assets as well as liabilities are netted against each other, whereas transactions in assets are not netted versus transactions in liabilities [IMF, 2004, 2005].
} 
Malović M.: A Mystery of the Global Surplus and its Ramification

Table 3 - World's (Aggregated) BoP Statistics (continued)

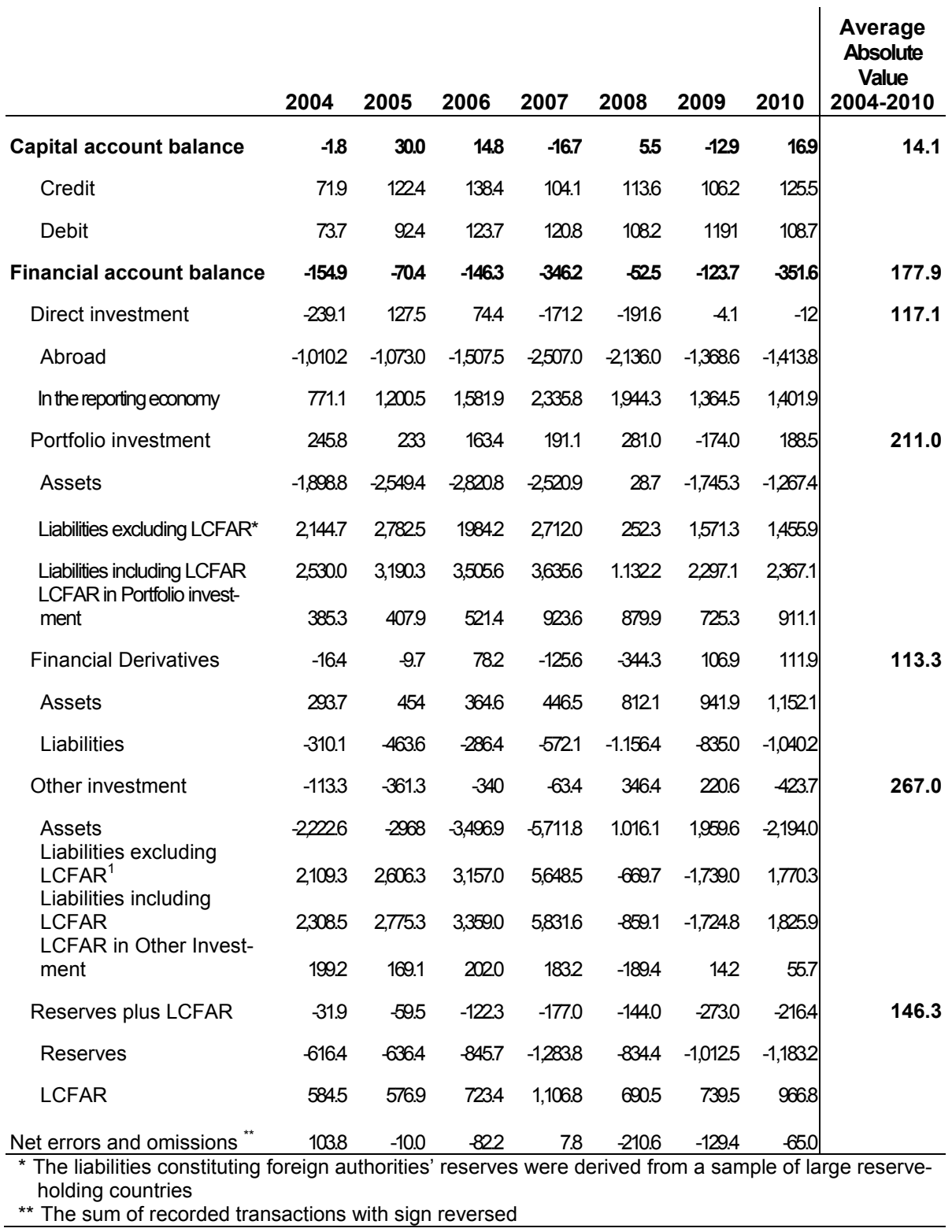

Source: IMF (2011) 


\section{Concluding Remarks}

This paper has tried to make sense of the global surplus mystery and pinpoint its chief determinants as well as its likely economic ramifications. In conclusion, it appears that:

- During overwhelming global financial crises quality and accuracy of the BoP statistics worsens worldwide, yet stocks dominate flows equally in economic significance of cumulative global imbalances (as measured by IIPs) and in significance of the global BoP disequilibrium even if incremental individual imbalances may look acceptable!

- Net global imbalances may still be much smaller than we commonly believe.

- True culprits may not be our usual suspects, neither in terms of countries (e.g. global surplus is not all about China), nor in regard to apparently crucial phenomena (e.g. to the extent it is about China it's not primarily due to 'grossly overvalued' yuan exchange rate).

- Gross trade reveals stark differences when decomposed into valueadded net exports and imports free of double counted processed exports and indirect exporting, and released from transfer pricing distortions.

- We have much to blame on asymmetric quality of BoP accounting across countries as well as asymmetric incentives a propos honest reporting of trade flows within countries

- Even the latest 6th edition of the IMF's BoP and IIP Manual doesn't treat returning surplus mystery as its top priority, neither normatively nor positively.

Still more work needs to be done in full and diligent implementation of existing IMF's BPM6, whereas more progress has to be made in designing better accounting techniques for grasping complex trade and financial flows unleashed by global supply chains, as well as in deeper understanding of BoP disequilibria and their true economic meaning. To that end, this essay is to be treated as a humble stepping stone towards the final scientific destination.

\section{References}

Bems, R., \& Johnson, R. (2012). Value-Added Exchange Rates. Cambridge, MA. NBER Working Paper.

Blanchard, O. (2007). Global Imbalances. Mexico City Lecture.

Bordo, M. (2005). Historical Perspective on Global Imbalances. Cambridge, MA. NBER Working Paper. 
Borio, C., \& Disyatat, P. (2011). Global Imbalances and Financial Crisis: Link or No Link. Basel: Monetary and Economis Department, Bank for International Settlements. BIS Working Paper.

Brender, A., \& Pisani, F. (2010). Global Imbalances and the Collapse of Globalized Finance. Brussels: Centre for European Policy Studies and Dexia Bank.

Caballero, R., Farhi, E., \& Gourinchas, (. (2008). An Equilibrium Model of 'Global Imbalances' and Low Interest Rates.American Economic Review, 98(1), 358-393.

Chinn, M., Eichengreen, B., \& Ito, H. (2011). Forensic Analysis of Global Imbalances. Cambridge, MA. NBER Working Paper.

Dunaway, S. (2009). Global Imbalances and the Financial Crisis. In Council's Special Report. New York, NY: Council on Foreign Relations, Center for Geoeconomic Studies.

-The Economist. (2011). Global Imbalances. printed issue, January 27th.

-The Economist. (2011). Economics Focus: Exports to Mars. printed issue, November 12th.

-The Economist. (2012). Global Imbalances: The Black Hole. printed issue, April 26th.

Gagnon, J. (2011). Current Account Imbalances Coming Back. Washington, DC: Peterson Institute for International Economics and Asian Development Bank. Working Paper.

Gagnon, J. (2012). Global Imbalances and Foreign Asset Expansion by DevelopingEconomy Central Banks. (pp. 12-15). Washington, DC: Peterson Institute for International Economics. Working Paper.

-IMF. (2004). Committee on Balance of Payments Statistics - Annual Report 2004. Washington, DC: International Monetary Fund.

-IMF. (2005). Committee on Balance of Payments Statistics - Annual Report 2005. Washington, DC: International Monetary Fund.

-IMF. (2009). Balance of Payments and International Investment Position Manual, 6th. Washington, DC: International Monetary Fund.

-IMF. (2010). Committee on Balance of Payments Statistics - Annual Report 2010. Washington, DC: International Monetary Fund.

-IMF. (2011). Committee on Balance of Payments Statistics - Annual Report 2011. Washington, DC: International Monetary Fund.

-IMF. (2012). World Economic Outlook. Washington, DC: International Monetary Fund. October.

Johnson, R., \& Noguera, G. (2011). Proximity and Production Fragmentation. In: 2012 AEA Meeting.

Johnson, R., \& Noguera, G. (2012). Fragmentation and Trade in Value Added over Four Decades. Cambridge, MA. NBER Working Paper.

Koopman, R., Wang, Z., \& Wei, S.J. (2012). Tracing Value-Added and Double Counting in Gross Exports. Cambridge, MA. NBER Working Paper.

Krugman, P.R., \& Obstfeld, M. (2000). International economics - theory and policy, 5th. Reading, MA: Addison-Wesley Publishing Company.

Mckinnon, R. (2006). China's Exchange Rate Trap: Japan Redux. American Economic Review, 96, 427-431.

Motala, J. (1997). Statistical Discrepances in the World Current Account. Finance \& Development, March.

Obstfeld, M. (2012). The Current Account and Global Financial Markets. In: IMF's Conference on "Analyzing (External) Imbalances", 2012-02-02, Washington, DC. International Monetary Fund. 
Reinhart, C., \& Rogoff, K. (2009). This Time is Different-Eight Centuries of Financial Folly. (pp. 209-211). Princeton and Oxford: Princeton University Press.

Song, Z., Storesletten, K., \& Zilibotti, F. (2011). Growing like China. American Economic Review, 101, 202-241.

Wheatley, A. (2013). China's Trade Surplus with U. S. may be a Quarter smaller. Reuters. January 16 th. 